\title{
ACUTE AND LONG-TERM EFFECTS OF GLUCOSE ON THE FUNCTION OF TRANSPLANTABLE RAT INSULINOMA CELLS MAINTAINED IN TISSUE CULTURE
}

\author{
Sara K. Swanston-Flatt and Peter R. Flatt \\ Department of Biochemistry, University of Surrey, Guildford, Surrey, GU2 5XH, U.K.
}

\begin{abstract}
Acute and long-term effects of glucose on B-cells from an X-ray induced transplantable rat insulinoma were examined in vitro. Fresh tumour cells failed to respond acutely to glucose or glucose plus theophylline with increased ${ }^{45} \mathrm{Ca}$ uptake and insulin release. During culture in RPMI-1640, blood cells and necrotic tumour cells rapidly disappeared. Cultured secretory cells did not proliferate but exhibited $>95 \%$ viability and consumed substantial amounts of glucose. Glucose (1.4$22.2 \mathrm{mM}$ ) did not affect insulin content or insulin release in 7-day cultures, but both parameters decreased by $51 \%$ and $80 \%$ compared with 2 -day cultures. Insulin output represented $1 \%$ of the fall in insulin content suggesting substantial cellular insulin degradation. Acute exposure of 2-day cultured cells to $16.7 \mathrm{mM}$ glucose did not affect insulin release $\left(64-88 \mathrm{ng} / 10^{6} \mathrm{cells} / \mathrm{h}\right)$ or ${ }^{45} \mathrm{Ca}$ uptake $(1.4-2.0 \mathrm{nmol} /$ $10^{6}$ cells $/ \mathrm{h}$ ). However, combination with $5 \mathrm{mM}$ theophylline evoked a $22-30 \%$ stimulatory insulin response. Cells cultured for 7 days also failed to respond acutely to glucose with increased ${ }^{45} \mathrm{Ca}$ uptake, but a $22-34 \%$ stimulation of insulin secretion was evident after maintenance at 5.6-22.2 but not $1.4 \mathrm{mM}$ glucose. Addition of theophylline potentiated the insulin response irrespective of a change in ${ }^{45} \mathrm{Ca}$ uptake.
\end{abstract}

Considerable interest has been generated by the availability of serially transplantable insulinomas in small laboratory animals. These have been produced in the rat by X-ray irradiation or streptozotocin-nicotinamide injection $(3,4)$, in the hamster by BK virus innoculation (15), and in the mouse by transfer into fertilised eggs of recombinant genes (12). Research conducted using these insulinomas has focused on two questions, namely what can these tumours tell us about human insulinomas, and secondly what might be learnt about pancreatic B-cell function by exploiting the availability of large amounts of insulinoma tissue. Despite these different approaches, interests have converged on the responsiveness of these insulinomas to glucose. Thus, glucose is not only recognised as the major physiological regulator of insulin secretion (27), but an inappropriately high rate of insulin secretion in the face of hypoglycaemia is also recognised as the cardinal feature of insulinoma (19).

The transplantable radiation-induced New England Deaconess Hospital (NEDH) rat insulinoma has a rapid growth rate and is composed of well granulated B-cells of high insulin content with only small amounts of other islet hormones and regulatory peptides $(5,22)$. These features together with the rapid formation of large vascularised tumours associated with hyperinsulinaemia and hypoglycaemia have made the NEDH rat insulinoma a most attractive model for research. However, there is considerable controversy in the literature concerning the in vivo and in vitro 
responsiveness of the tumour to glucose. Thus whereas some authors report insensitivity of the tumour to glucose $(10,25)$, others report that glucose exerts a prominent insulin response $(16,20)$. Interpretation of these data is complicated by the contribution of endocrine pancreas to the insulin response in vivo, and the trauma imposed by tissue preparation for in vitro studies. Furthermore, these experimental approaches cannot dissociate the responsiveness of the tumour per se from the functional consequences of prolonged exposure to hypoglycaemia in vivo. Indeed, culture for 6-7 days at low extracellular glucose concentration has been shown to practically abolish the insulin secretory response to glucose in normal pancreatic B-cells $(1,24)$.

In the present study we have made a detailed investigation of the acute and longterm effects of glucose on the function of transplantable NEDH rat insulinoma cells maintained in tissue culture. The use of tissue culture has several advantages including stabilisation of cell function, elimination of necrotic tumour cells and maintenance of cells in a controlled in vitro environment. In addition to evaluating insulin release and cellular insulin content, measurements of ${ }^{45} \mathrm{Ca}$ uptake have been performed to elucidate the involvement of transmembrane $\mathrm{Ca}^{2+}$ fluxes in the regulation of insulin release from the tumour cells.

\section{MATERIALS AND METHODS}

\section{Animals and Transplantation}

Male inbred NEDH rats from the colony at the University of Surrey carrying a serially transplantable radiation-induced insulinoma (4) were used at 16-17 weeks of age. The origin of these rats has been described elsewhere (8). Single subcutaneous subscapular tumours (subline SF A/3) from donor NEDH rats were used as the source of tumour fragments for transplantation. Each tumour was rapidly excised, the capsule was removed and the contents finely minced. Recipient rats were lightly anaesthetised with ether, and $0.1 \mathrm{ml}$ of minced tumour was implanted into the subscapular region using a 16 gauge needle. The rats were housed in an air-conditioned room at $22 \pm 2^{\circ} \mathrm{C}$ with a lighting schedule of $12 \mathrm{~h}$ light (0700-1900) and $12 \mathrm{~h}$ dark. A standard pellet diet (Spratts Laboratory Diet 1, Lillico, Reigate, U.K.) and tap water were supplied $a d$ libitum.

\section{Isolation and Culture of Tumour Cells}

Tumours weighing approximately 2-6 g were excised from recipient rats approximately 24 days after implantation of tumour fragments. Plasma glucose and insulin concentrations at the time of tumour excision were in the region of $1.8 \mathrm{mM}$ and $20 \mathrm{ng} / \mathrm{ml}$, respectively. The tumour capsule was removed from each tumour, and the constituent cells were harvested following gentle mechanical disruption and filtration through nylon mesh (pore size $56 \mu \mathrm{m})$ to remove connective tissue fragments. It was not necessary to use collagenase or trypsin for the preparation of cell suspensions. The isolated cells were extensively washed with culture medium containing $1.4 \mathrm{mM}$ glucose, and finally plated in plastic Petri dishes (Nunc, Roskilde, Denmark) at a concentration of $5 \times 10^{5}$ live tumour cells $/ \mathrm{ml}$. Cell viability assessed by trypan blue exclusion was approximately $40 \%$, and the number of blood cells in these initial cultures was similar to the total number of tumour cells. Isolated cells were cultured for up to 7 days at $37^{\circ} \mathrm{C}$ in a humidified atmosphere of $5 \% \mathrm{CO}_{2}$ in air. The culture medium was RPMI-1640 (Gibco Europe, Paisley, U.K.) containing 10\% foetal calf serum, antibiotics $(100 \mu / \mathrm{ml}$ penicillin and $0.1 \mathrm{mg} / \mathrm{ml}$ streptomycin; Gibco Europe, Paisley, U.K.) and either 1.4, 5.6, 11.1 or $22.2 \mathrm{mM}$ glucose. The medium was changed at 2 and 5 days. By 2 days, only occasional blood cells were observed by phase contrast microscopy. The viability of tumour cells at 2 , 5 and 7 days was greater than 95\%. Cellular glucose consumption over this period, estimated from measurements of medium glucose concentrations was approximately 1.6 $\mu \mathrm{mol} / 10^{6}$ cells $/ 7$ days. The number of viable tumour cells did not change during culture. The cells did not attach to the plastic dishes and were present either singly or in small clusters.

\section{Insulin Release and Cellular Insulin Content during Culture}

Aliquots of culture media were removed at 2 , 5 and 7 days, centrifuged $\left(150 \mathrm{~g}, 10 \mathrm{~min}, 4^{\circ} \mathrm{C}\right)$ to eliminate cells, and stored at $-20^{\circ} \mathrm{C}$ for insulin determination. The insulin content of the heat-inactivated calf serum made a negligible contribution to the insulin concentrations measured in the media. At 2 and 7 days of culture, tumour cells were disrupted by 
sonication and extracted overnight at $4^{\circ} \mathrm{C}$ using acid ethanol $(75 \mathrm{ml}$ ethanol, $25 \mathrm{ml}$ distilled water, $1.5 \mathrm{ml}$ concentrated hydrochloric acid). Extracts were stored at $-20^{\circ} \mathrm{C}$ for insulin assay.

\section{Insulin Release and ${ }^{45} \mathrm{Ca}$ Uptake during Acute Incubations}

Insulin release and ${ }^{45} \mathrm{Ca}$ uptake studies were performed using 2-day and 7-day cultured cells. In a single experiment, freshly isolated (non-cultured) tumour cells were used. Approximately $2.5 \times 10^{6}$ viable tumour cells were incubated in $100 \mu \mathrm{l}$ modified Krebs-Ringer bicarbonate buffer ( $\mathrm{pH}$ 7.4) containing $20 \mathrm{mM}$ $N$-2-hydroxyethyl-piperazine - $N^{\prime}$-2 - ethanesulphonic acid (HEPES), $115 \mathrm{mM} \mathrm{NaCl}, 24 \mathrm{mM}$ $\mathrm{NaHCO}_{3}, 4.7 \mathrm{mM} \mathrm{KCl}, 2.6 \mathrm{mM}{ }^{45} \mathrm{CaCl}_{2}(7.8$ $\mathrm{Ci} / \mathrm{mol}$; Amersham International, Amersham, U.K.), $1.2 \mathrm{mM} \mathrm{KH}_{2} \mathrm{PO}_{4}, 1.2 \mathrm{mM} \mathrm{MgSO}{ }_{4}$ and $5 \mathrm{mg} / \mathrm{ml}$ bovine serum albumin. The buffer was supplemented with glucose and $5 \mathrm{mM}$ theophylline (Sigma Chemical Co., Poole, U.K.) as indicated in the figures. The cells were incubated in duplicate for $60 \mathrm{~min}$ at $37^{\circ} \mathrm{C}$ in polyethylene microfuge tubes $(400 \mu \mathrm{l} \mathrm{ca}-$ pacity). At the end of incubation, the cells were separated by centrifugation (Beckman microfuge type $\mathbf{B} ; 15,000 \mathrm{~g}$ for $2 \mathrm{~min}$ ) through an underlaying layer of oil ( $200 \mu$ lof a mixture of dibutyl- and dinonylphthalate, $10: 3 \mathrm{v} / \mathrm{v}$ ) into urea $(20 \mu \mathrm{l}, 6 \mathrm{M})$. Aliquots of supernatant buffer were stored at $-20^{\circ} \mathrm{C}$ for insulin determination. The ${ }^{45} \mathrm{Ca}$ content of the cell pellet in the cut tip of the tube was determined by liquid scintillation spectrometry following the addition of $2 \mathrm{ml}$ Picofluor-15 (Packard Instruments, Caversham, U.K.). Samples of the labelled incubation medium $(5 \mu \mathrm{l})$ were used as external standards in the counting procedure. The cell content of ${ }^{45} \mathrm{Ca}$ was expressed as nmol of calcium $/ 10^{6}$ cells with the same specific radioactivity as that of the incubation medium.

\section{Assays}

Plasma glucose was determined by an automated glucose oxidase procedure using a Beckman glucose analyser (Beckman Rlic, High Wycombe, U.K.). Insulin was measured by dextran-charcoal radioimmunoassay (7) using a rat insulin standard (Novo Industria, Copenhagen, Denmark). Parallelism was demonstrated between the insulin standard curve and serial dilutions of either plasma or the samples derived from cultured cells.

\section{Statistical Analysis}

Groups of data are presented at means \pm SEM. Statistical evaluation was performed using Student's paired and unpaired $t$-tests. Differences were considered to be significant for $P<0.05$.

\section{RESULTS}

\section{Insulin Release and Cellular Insulin Content during Culture}

As shown in Fig. 1, tumour cells released approximately $200 \mathrm{ng}$ insulin $/ 10^{6}$ cells into the medium during 7 day cultures. Increasing the glucose concentration in the medium from 1.4 to $5.6,11.1$ or $22.2 \mathrm{mM}$ did not affect the amount of insulin released during $0-2$ days, 25 days or 5-7 days of culture. The relatively high rate of insulin accumulation in the medium during the first 2 days of culture may be partly attributed to a high basal release from freshly isolated cells (compare insulin release data in Figs. 3 and 4), and the degradation of necrotic tumour cells. Glucose did not affect the total output of insulin from the cells during the 7-day culture period.

The effects of glucose on the cellular insulin content at 2 days and 7 days of culture are shown in Fig. 2. Compared with 2-day cultured cells, the cellular insulin content was decreased by approximately 51\% after 7 days. Raising the glucose concentratin in the medium from $1.4 \mathrm{mM}$ to $22.2 \mathrm{mM}$ did not appreciably affect the cellular insulin content. The insulin content of cells cultured for 2 days at $5.6 \mathrm{mM}$ glucose was less than that of cells cultured at $1.4 \mathrm{mM}$ glucose for the same period.

Comparison of the changes in cellular insulin content during 2-days and 7-days of culture (50-100 $\mu \mathrm{g} / 10^{6}$ cells) with the corresponding total insulin output (approximately $0.5 \mu \mathrm{g} / 10^{6}$ cells) indicates that only $1 \%$ of the fall in cellular insulin can be attributed to release into culture medium. Since insulin degradation in the culture medium was $10-15 \%$, these results are suggestive of substantial cellular insulin degradation.

\section{Insulin Release and ${ }^{45} \mathrm{Ca}$ Uptake during Acute Incubations}

The effects of glucose and theophylline on 

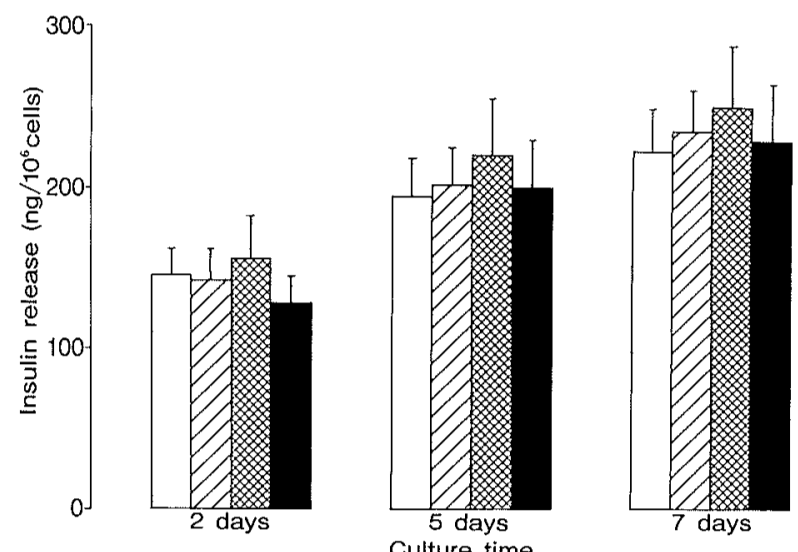

Fig. 1 Insulin release by rat insulinoma cells during 7 days of culture in RPMI-1640 containing either $1.4 \mathrm{mM}$ glucose

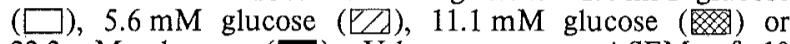
$22.2 \mathrm{mM}$ glucose ( $(\mathbb{a})$. Values are mean \pm SEM of 10 tumours.
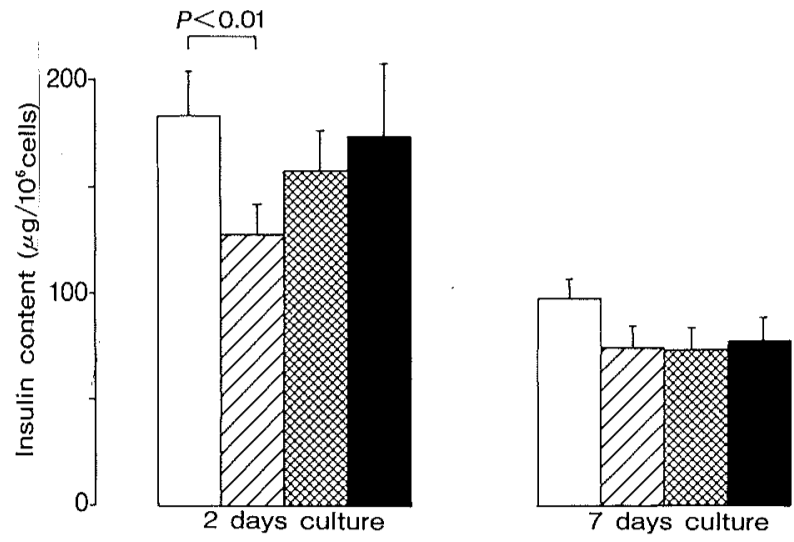

Fig. 2 Insulin content of rat insulinoma cells after 2 and 7 days culture in RPMI-1640 containing either $1.4 \mathrm{mM}$ glucose

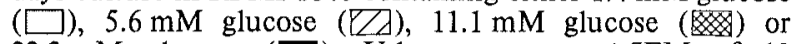
$22.2 \mathrm{mM}$ glucose ( () . Values are mean $\pm S E M$ of 10 tumours.

insulin release and ${ }^{45} \mathrm{Ca}$ uptake during acute $60 \mathrm{~min}$ incubations were examined using freshly isolated tumour cells, and cells cultured for 2 or 7 days at 1.4, 5.6, 11.1 or $22.2 \mathrm{mM}$ glucose. As shown in Fig. 3, freshly isolated tumour cells released $250-450 \mathrm{ng}$ / $10^{6}$ cells/h during acute incubations with the concomitant uptake of $16-22 \mathrm{nmol}{ }^{45} \mathrm{Ca}$. Addition of $16.7 \mathrm{mM}$ glucose alone or in combination with theophylline did not affect either parameter.

After 2-days culture at $1.4-22.2 \mathrm{mM}$ glucose, acute exposure to $16.7 \mathrm{mM}$ glucose did not significantly stimulate insulin release (Fig. 4). Combination of glucose with theophylline, evoked a secretory response from cells cultured at 1.4 and $5.6 \mathrm{mM}$ glucose. The accompanying ${ }^{45} \mathrm{Ca}$ uptake by these cells is shown in Fig. 5. Glucose alone or in combination with theophylline did not affect ${ }^{45} \mathrm{Ca}$ uptake with the exception of an inhibitory effect in one instance.

The effects of extending the culture period to 7 days on acute insulin release are shown in Fig. 6. In this instance, $16.7 \mathrm{mM}$ glucose significantly increased insulin release from cells 
Insulin release
$\left(\mathrm{ng} / 10^{6} \mathrm{cells} / 60 \mathrm{~min}\right)$

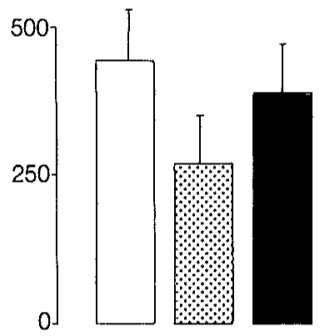

${ }^{45}$ Calcium uptake (nmol $/ 10^{6}$ cells $/ 60 \mathrm{~min}$ )

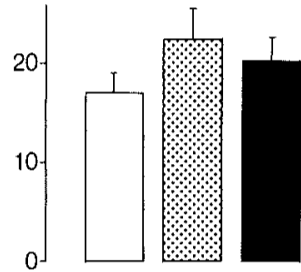

Fig. 3 Insulin release and ${ }^{45} \mathrm{Ca}$ uptake by freshly isolated rat insulinoma cells during acute incubations at $0 \mathrm{mM}$ glucose $(\square), 16.7 \mathrm{mM}$ glucose (․) or $16.7 \mathrm{mM}$ glucose plus $5 \mathrm{mM}$ theophylline (a). Values are mean \pm SEM of 8 tumours.

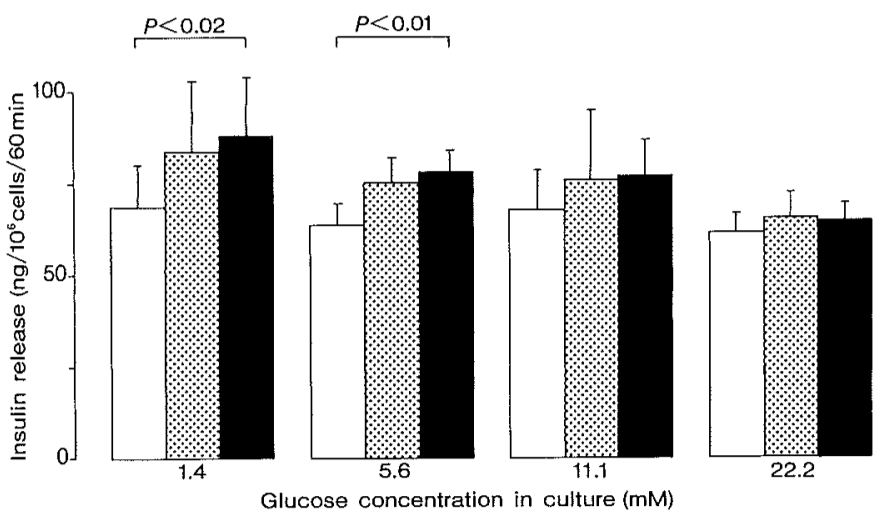

Fig. 4 Insulin release by 2-day cultured rat insulinoma cells during acute incubations at $0 \mathrm{mM}$ glucose $(\square), 16.7 \mathrm{mM}$ glucose () or $16.7 \mathrm{mM}$ glucose plus $5 \mathrm{mM}$ theophylline ( $\square)$. Values are mean $\pm S E M$ of 8 tumours.

cultured at $5.6,11.1$ or $22.2 \mathrm{mM}$ glucose. Glucose plus theophylline also increased insulin release compared with incubations at $0 \mathrm{mM}$ glucose. In contrast to these stimulatory effects, glucose alone or with theophylline did not increase ${ }^{45} \mathrm{Ca}$ uptake (Fig. 7). Inhibition was actually observed in one instance.

Compared with freshly isolated tumour cells (Fig. 3), insulin release and ${ }^{45} \mathrm{Ca}$ uptake were substantially less with cultured insulinoma cells (Figs. 4-7).

\section{DISCUSSION}

The present study has exploited tissue culture techniques established for pancreatic B-cells to evaluate the acute and long-term effects of glucose on the function of transplantable rat insulinoma cells. The culture of rat insulinoma cells was associated with disappearance of contaminating blood cells and necrotic tumour 'cells providing a purified source of tumour cells with $>95 \%$ viability. Since previous studies have shown that this tumour contains only very small amounts of regulatory peptides other than insulin $(5,22)$, it is not unreasonable to assume that the tumour cells are almost entirely insulin-secreting B-cells. Interestingly, the cells did not attach to plastic dishes nor proliferate like the derived RINm5F cell line (11). However, cell function was well preserved as indicated by trypan blue 


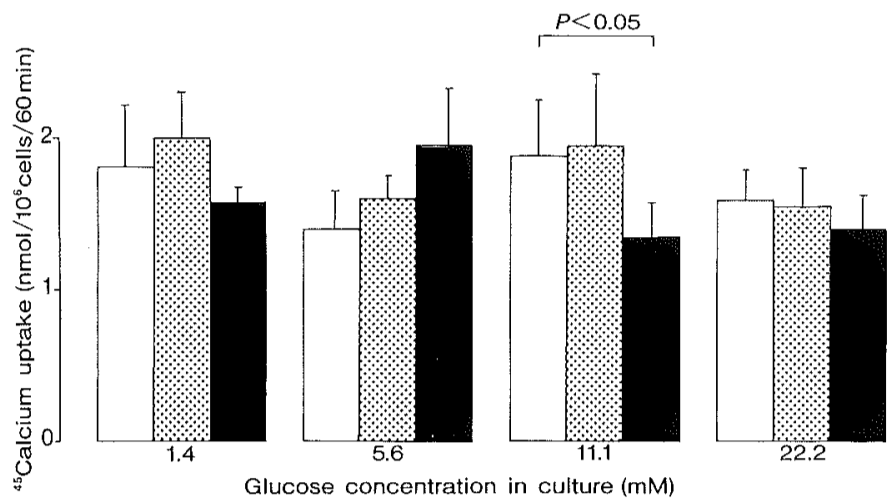

Fig. $5{ }^{45} \mathrm{Ca}$ uptake by 2-day cultured rat insulinoma cells during acute incubations at $0 \mathrm{mM}$ glucose $(\square), 16.7 \mathrm{mM}$ glucose (ख) or $16.7 \mathrm{mM}$ glucose plus $5 \mathrm{mM}$ theophylline ( Values are mean \pm SEM of 8 tumours.

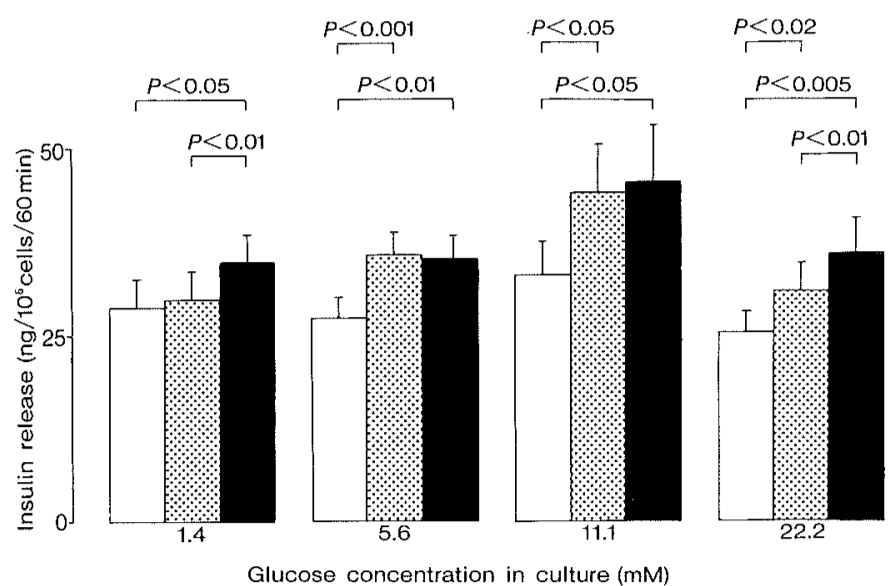

Fig. 6 Insulin release by 7-day cultured rat insulinoma cells during acute incubations at $0 \mathrm{mM}$ glucose $(\square), 16.7 \mathrm{mM}$ glucose (궁 or $16.7 \mathrm{mM}$ glucose plus $5 \mathrm{mM}$ theophylline (ם). Values are mean \pm SEM of 8 tumours.

exclusion, substantial glucose consumption, continued release of insulin and the ability of cultured cells to reform tumours giving rise to fatal hyperinsulinaemia and hypoglycaemia in recipient NEDH rats (8).

As shown by long-term culture, glucose did not affect the accumulation of insulin in the culture medium or the insulin content of the tumour cells. This failure to affect insulin release contrasts with the stimulatory effects observed with pancreatic B-cells (1), but is consistent with the lack of effect of prolonged hyperglycaemia on tumour growth and circulating insulin concentrations in vivo (9). Comparison of the insulin output during culture with changes in cellular insulin content suggest that there was substantial intracellular degradation of insulin in the tumour cells. This view is compatible with the demonstration of insulin degrading activity in human insulinomas and cell lines established from the rat insulinoma $(2,17)$.

Consistent with other observations (25), glucose failed to acutely stimulate insulin re- 


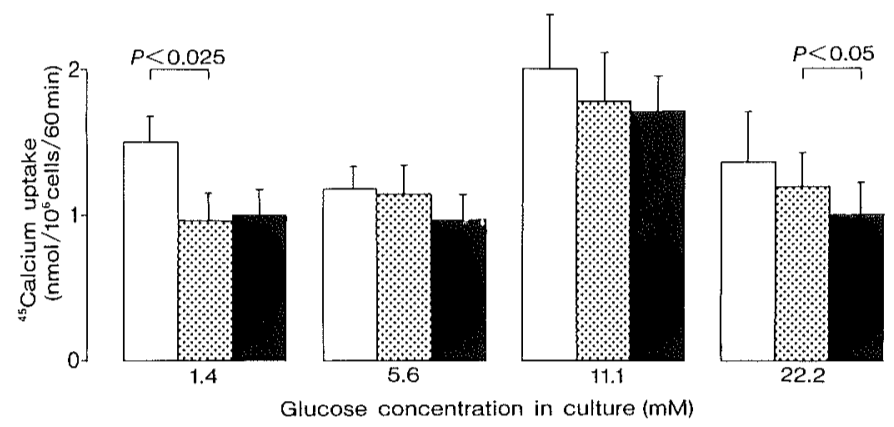

Fig. $7{ }^{45} \mathrm{Ca}$ uptake by 7 -day cultured rat insulinoma cells during acute incubations at $0 \mathrm{mM}$ glucose $(\square), 16.7 \mathrm{mM}$ glucose (D) or $16.7 \mathrm{mM}$ glucose plus $5 \mathrm{mM}$ theophylline ( $)$. Values are mean \pm SEM of 8 tumours.

lease from freshly isolated tumour cells during incubations in vitro. Addition of the phosphodiesterase inhibitor, theophylline, also failed to enhance insulin release under these circumstances. However, the rates of insulin release and ${ }^{45} \mathrm{Ca}$ uptake in these experiments were as much as 10 -fold greater than with cultured cells, suggesting that high basal insulin release and ${ }^{45} \mathrm{Ca}$ uptake were a consequence of using damaged and necrotic tumour cells. After 2days of culture at glucose concentrations ranging from $1.4 \mathrm{mM}$ (equivalent to the hypoglycaemia of insulinoma-bearing rats) to 22.2 $\mathrm{mM}$, glucose similarly failed to acutely stimulate insulin release or ${ }^{45} \mathrm{Ca}$ uptake. These combined data accord with the failure of tumour cells to respond acutely to glucose in vivo (9) and indicate that this unresponsiveness is linked to the inability of the sugar to elicit the changes of $\mathrm{Ca}^{2+}$ flux typical for normal B-cells $(14,27)$.

The suggestion that elevation of intracellular cyclic AMP was capable of enhancing insulin release from 2-day cultured cells was endorsed by the results obtained after 7-days of culture. In these circumstances, glucose plus theophylline consistently stimulated insulin release. Indeed cells cultured at 5.6, 11.1 or $22.2 \mathrm{mM}$ glucose also responded acutely to glucose with enhanced secretion. Such an effect was not observed using cells cultured at $1.4 \mathrm{mM}$ glucose, raising the possibility that reversal of the hypoglycaemic environment was responsible for the glucose responsiveness. However, as indicated by the lack of effect of glucose on ${ }^{45} \mathrm{Ca}$ uptake under these conditions, the tumour cells clearly exhibit a fundamental defect not attributable to hypoglycaemia or unchecked cell division. Thus, the stimulatory effects of glucose on 7-day cultured cells cannot be attributed to modification of transmembrane $\mathrm{Ca}^{2+}$ fluxes as established for normal pancreatic B-cells $(14,27)$. The effects of theophylline on tumour cells are also unlikely to be due to an increase in cytoplasmic $\mathrm{Ca}^{2+}$. Thus elevation of cyclic AMP in $o b / o b$ mouse B-cells did not affect cytoplasmic $\mathrm{Ca}^{2+}$, as measured using the fluorescent $\mathrm{Ca}^{2+}$-indicator quin-2 (23). It is possible that cyclic AMP sensitises the secretory machinery to $\mathrm{Ca}^{2+}$ to elicit insulin release (14). However, in common with other cancer cells (6), cultured insulinoma cells already exhibit extreme sensitivity to $\mathrm{Ca}^{2+}$ as witnessed by the independence of insulin release on extracellular $\mathrm{Ca}^{2+}(26)$. It therefore seems likely that the effect of theophylline is mediated through other mechanisms, possibly related to the ability of cyclic AMP to activate protein kinases in B-cells (13).

The instatement of an insulin response to glucose in these tumour cells without change in ${ }^{45} \mathrm{Ca}$ uptake is intriguing. The lack of glucose recognition by the rat insulinoma has been attributed to a marked depletion of glucokinase with a corresponding increase of hexokinase $(18,21)$. Perhaps the environment in culture has addressed the glucose phosphorylation activity in favour of glucokinase, or induced a coupling system capable of enhancing insulin secretion in tumour cells without involvement of $\mathrm{Ca}^{2+}$. Despite such uncertainties, the present study clearly indicates that the ability of glucose to stimulate 
insulin release from rat insulinoma cells is subject to long-term modulation by the cellular environment. Discrepancies in the literature concerning the ability of glucose to regulate these cells may partly reflect differences in tumour environment, experimental design and the divergent characteristics of tumour sublines.

These studies were supported by a grant from the Cancer Research Campaign (SP 1630).

Received for publication 6 May 1987

\section{REFERENCES}

1. Andersson A., Gunnarsson R. and HellerSTRÖM C. (1976) Long-term effects of a low extracellular glucose concentration on glucose metabolism and insulin biosynthesis and release of mouse pancreatic islets maintained in tissue culture. Acta Endocrinol. 82, 318329

2. Bhathena S. J., Timmers K. I., Oie H. K., Voyles N. R. and Recant L. (1985) Cytosolic insulin-degrading activity in islet-derived tumor cell lines and in normal rat islets. Diabetes 34, 121-128

3. Chick W. L., Appel M. C., Weir G. C., Like A. A., Lauris V., Porter J. G. and Chute R. N. (1980) Serially transplantable chemically induced rat islet cell tumor. Endocrinology 107, 954-960

4. Chick W. L., Warren S., Chute R. N., Like A. A., Lauris V. and Kitchen K. C. (1977) A transplantable insulinoma in the rat. Proc. Natl. Acad. Sci. USA 74, 628-632

5. Conlon J. M., Deacon C. F., Bailey C. J. and Flatt P. R. (1986) Effects of a transplantable insulinoma upon regulatory peptide concentrations in the gastrointestinal tract of the rat. Diabetologia 29, 334-338

6. Durham A. C. H. and Walton J. M. (1982) Calcium ions and the control of proliferation in normal and cancer cells. Bioscience Rep. 2, 1530

7. Flatt P. R. and Bailey C. J. (1981) Abnormal plasma glucose and insulin responses in heterozygous lean $(o b /+)$ mice. Diabetologia 20, 573577

8. Flatt P. R., Bailey C. J., Gray C. and Swanston-FlatT S. K. (1986) Metabolic effects of radiation induced rat insulinoma at pancreatic, hepatic and subscapular transplantation sites. Comp. Biochem. Physiol. 85A, 183-186

9. Flatt P. R., Bailey C. J., Swanston-Flatt S. K., TAN K. S. and MARKS V. (1987) Reversal of diabetes by syngeneic transplantation of a radiation-induced rat insulinoma. Diabetes Res. Clin. Prac. 3, 63-69

10. Flatt P. R. and Swanston-Flatt S. K. (1985)
Role of calcium in defective insulin secretion from human and transplantable rat islet cell tumours. Biomed. Biochim. Acta 44, 71-75

11. Gazdar A. F., Chick W. L., Oie H. K., Sims H. L., King D. L., Weir G. C. and LaURIS V. (1980) Continuous, clonal, insulin- and somatostatinsecreting cell lines established from a transplantable rat islet cell tumour. Proc. Natl. Acad. Sci. USA 77, 3519-3523

12. Hanahan D. (1985) Heritable formation of pancreatic $\beta$-cell tumours in transgenic mice expressing recombinant insulin/simian virus 40 oncogenes. Nature 315, 115-122

13. Harrison D. E., Ashcroft S. J. H., Christie M. R. and Lord J. M. (1984) Protein phosphorylation in the pancreatic B-cell. Experientia 40, 1075-1084

14. Hellman B., Andersson T., Berggren P.-O., Flatt P. R, Gylfe E. and Kohnert K. D. (1979) The role of calcium in insulin secretion. In Hormones in Cell Regulation Vol. 3 (ed. Dumont J. and Nunez J.) North Holland Biomedical Press, Amsterdam, pp. 69-96

15. Hirayama A., Wakabayashl I., Muto T., Watanabe S. and UChida S. (1979) Histological and hormonal observations on the $\mathrm{BK}$ virus induced pancreatic islet-cell tumours in hamsters. In Proinsulin, Insulin and $C$-peptide (ed. BabA S., Kaneto $T$. and YanalHara N.) Excerpta Medica, Amsterdam, pp. 364-373

16. Hoenig M., Ferguson D. C. and Matchinsky F. M. (1984) Fuel-induced insulin release in vitro from insulinomas transplanted into the rat kidney. Diabetes 33, 1-7

17. Kohnert K.-D., Hehmke B., Woltanski K.-P., Ulrich F. E. and ZüHLke H. (1983) Thiol-protein disulfide oxidoreductase and peptidase activities in insulinoma tissue. Biomed. Biochim. Acta 42, 1091-1101

18. Lenzen S., Tiedge M., Flatt P. R., Bailey C. J. and PANTEN U. (1987) Defective regulation of glucokinase in rat pancreatic islet cell tumours. Acta Endocrinol. 115 (in press)

19. Marks V. and Rose F. C. (1981) Hypoglycaemia. Second Ed., Blackwell Scientific Publications, Oxford

20. Masiello P., Wollheim C. B., Janjic D., Guinovici A., Blondel B., Praz G. and Renold A. E. (1982) Stimulation of insulin release by glucose in a transplantable rat islet cell tumor. Endocrinology 111, 2091-2096

21. Meglasson M. D., Burch P. T., Hoenig M., Chick W. L. and Matschinsky F. M. (1983) Identification and significance of glucokinase in transplantable insulinomas. J. Biol. Chem. 258, 2094-2097

22. O'Hare M. M. T., Shaw C., Swanston-Flatt S. K., Marcelli M., Buchanan K. D. and Flatt P. R. (1985) Influence of a transplantable insulinoma on the pancreatic status of insulin and pancreatic polypeptide in the rat. Diabetologia 28, $157-160$ 
23. Rorsman P. and Abrahamsson H. (1985) Cyclic AMP potentiates glucose-induced insulin release from mouse pancreatic islets without increasing cytosolic free $\mathrm{Ca}^{2+}$. Acta Physiol. Scand. 125, 639-647

24. Siegel E. G., Wollheim C. B., Janjic D., Ribes G. and SHARP G. W. G. (1983) Involvement of $\mathrm{Ca}^{2+}$ in the impaired glucose-induced insulin release from islets cultured at low glucose. Diabetes 32, 993-1000

25. Sopwith A. M., Hutton J. C., NAber S. P.,
CHick W. L. and Hales C. N. (1981) Insulin secretion by a transplantable rat islet cell tumour. Diabetologia 21, 224-229

26. Swanston-Flatt S. K. and Flatt P. R. (1987) Effects of cationic modification on ${ }^{45} \mathrm{Ca}$ uptake and insuline release by transplantable rat insulinoma cells maintained in tissue culture. Gen. Pharmacol. (in press)

27. Wollheim C. B. and Sharp G. W. G. (1981) Regulation of insulin release by calcium. Physiol. Rev. 61, 914-973 